\title{
First report of Penicillium glaucum Link causing Penicillium rot of pear fruits Pyrus communis L. in Jammu and Kashmir, India
}

\section{Shazia Parveen*, Abdul Hamid Wani, Mohd Yaqub Bhat, Tariq Ahmad Wani and Abdul Rashid Malik}

Section of Mycology and Plant Pathology, Department of Botany, University of Kashmir- 190006. Email*shahshazia442@gmail.com.

\begin{abstract}
Pears Pyrus communis L. collected from different sites of Kashmir Valley were found infected with Penicillium glaucum causing Penicillium rot. The diseased fruits appears light tan to dark brown. The decayed tissue becomes soft, watery and the lesion has a very sharp margin between diseased and healthy tissues. Decayed fruit has an earthy, musty odor. The pathogen was isolated and cultured on PDA medium for further fungal morphological observation and confirming its pathogenicity according to Koch's postulates. Results of morphological data and pathogenicity test showed that the pears were infected by Penicillium glaucum Link resulting in Penicillium rot of pears. To our knowledge, it is the first report of pear fruit rot caused by P. glaucum in India. Study was also undertaken for the management of Penicillium rot of pear with some fungicides. It was revealed from the study that different concentration of fungicides brought about significant reduction in the mycelial growth and spore germination of Penicillium glaucum under in vitro conditions. Amongst the tested fungicides, carbendazim proved highly effective in inhibiting the mycelial growth and spore germination of Penicillium glaucum followed by hexaconozole, bitertanol and myclobutanil respectively. Higher concentration proved effective than lower concentrations.
\end{abstract}

Keywords: Blue mould; Post-harvest rots; Kashmir Valley; Fungicides.

\section{Introduction}

Fruits are important sources of essential nutrients, vitamins, minerals and are a major source of complex carbohydrates, antioxidants and anti-
Received

September 08, 2017

Accepted

December 06, 2017

Released

December 31, 2017

Open Access

Full Text Article

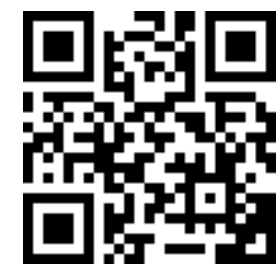

ORCII

(1) 0000-0002-0086-2685 Shazia Parveen

(1) 0000-0002-6157-9656 Abdul Hamid Wani

(i) 0000-0002-0582-4813 Mohd Yaqub Bhat

(1) 0000-0002-0631-7610 Tariq Ahmad Wani

(D) 0000-0001-6775-3590

Abdul Rashid Malik carcinogenic substances which are important for human health. Pear fruits are rich sources of vitamin C, dietary fiber, malic acid, citric acid, quinic acid, $\alpha-$ ketoglutaric acid, succinic acid, lactic acid, glycolic acid, shikimic acid, glyceric acid 
and mucic acid (Blattny, 2003; Colaric et al., 2005). Pear fruits are also known to have pharmacological properties like antiinflammatory, anti-tumour and antiallergic, due to presence of little amount salicylates and benzoates present in the fruit (Macheix et al., 1990). The fruit production is facing threats by many post harvest diseases, the principal cause being the fungal diseases. The pear fruits are more vulnerable to post harvest diseases due to their perishable nature, little shelf life etc. The threat of these diseases is influenced by the way these horticultural crops are handled and stored. The fungal rot diseases caused heavy losses to the fruits in storage, transit as well as in fields. As per literature fungal rot of fruits cause huge losses upto $30 \%$ to the growers in terms of yield (BarkaiGolan, 2001; Bhale, 2011) and therefore, needs proper management in storage and under field conditions

The aim of the present study was to identify the fungal pathogen associated with pears in Kashmir Valley and to study the effect of different fungicides on the causal pathogen.

\section{Materials and methods}

To investigate the fungi which cause the rotting of pear fruits in Kashmir Valley, diseased pear fruits were collected in separate polythene bags from different fields, markets, godowns and storage houses of Kashmir valley. These samples were either used immediately or stored at $10^{\circ} \mathrm{C}$ in the laboratory for different pathological studies. Small portions of rotted tissues were isolated aseptically from the diseased pear fruits and transferred to Potato Dextrose Agar (PDA) medium. Pure colony cultures were obtained by subculturing the fungal growth in separate Petri plates containing the same medium. The pathogen was identified by their morphological, reproductive and cultural characteristics (Ellis, 1971; Barnett and Hunter, 1972; Watanabe, 2002; Gilman, 2008). For pathogenicity, pathogens were re-inoculated after isolation onto the healthy pear fruits (Tomkin and Trout, 1931). Then all the fruits were kept in clean polythene bags and incubated at $25 \pm 2{ }^{\circ} \mathrm{C}$ for ten days. These pathogenicity tests were used for the identification of plant pathogens and to confirm the detection of a particular disease. Identification of the disease and the pathogen was done following Koch's postulates. Different parameters such as symptoms caused by these fungi on the healthy pear fruits, cultural characteristics of the pathogens and microscopic studies of the pathogens were studied.

In the present study an attempt was made to study the effect of some selected fungicides under in vitro conditions for the control of Penicillium rot of pears caused by Penicillium glaucum.

\section{Methodology}

Different concentrations $\quad(1,000$ ppm, 800 ppm, 600 ppm, 400 ppm and 200 $\mathrm{ppm}$ ) of fungicides viz. carbendazim, hexaconozole, bitertanol and myclobutanil were prepared in sterilized distilled water. These different concentrations of fungicides were evaluated for their effect on mycelial growth of rot causing fungi, Penicillium glaucum by food poisoning technique (Adams and Wong, 1991). Appropriate concentration $(1 \mathrm{~mL})$ of fungicide solution was mixed with autoclaved and cooled PDA (9 mL) just before pouring into Petri plates. The medium was then dispensed uniformly into $90 \mathrm{~mm}$ diameter Petri plates and inoculated with $5 \mathrm{~mm}$ mycelial disc of the pathogen from 10 day old fungal culture. Three replicates were maintained for each concentration including control without any treatment. The Petri plates were incubated at $25 \pm 2{ }^{\circ} \mathrm{C}$ and observations of the mycelial growth of test fungus were recorded after seven days of incubation. The percent inhibition in mycelial growth due to various fungicidal treatments at different concentrations was computed as follows:

$$
\text { Mycelial growth inhibition }(\%)=\frac{\mathrm{dc}-\mathrm{dt}}{\mathrm{dt}} \times 100
$$


Where dc $=$ average diameter of fungal colony in control, and $\mathrm{dt}=$ average diameter of fungal colony in treatment group.

For studying the effect of fungicides on spore germination, spore suspension was prepared in sterilized distilled water. Equal volume of spore suspension and the fungicide solutions were mixed in a test tube and then shaken. The mixture then contained the particular concentration of test fungicide. In case of control spore suspension was mixed with equal volume of distilled water. A drop of the mixture (about $0.1 \mathrm{~mL}$ ) was then placed in the cavity slide and these were incubated for $25 \pm 2^{\circ} \mathrm{C}$ in a moist chamber to maintain enough humidity. Three replicates were maintained for each treatment including the control. The slides were examined after 24hrs by hand tally counts at different microscopic fields. Percent spore germination of each treatment was calculated by the formula given by Kiraly et al. (1974).

$$
\text { Percent spore germination }=\frac{\text { No.of spores germinated }}{\text { Total no.of spores examined }} \times 100
$$

\section{Results and discussion}

It was observed from the present study that pears in storage are infected by the fungus, Penicillium glaucum Link resulting in Penicillium mold rot of pears. The casual pathogen was identified on the basis of symptoms caused by the fungus on pear fruits, cultural and microscopic characteristics. On the diseased fruits the decayed area appears light tan to dark brown. The decayed tissue becomes soft, watery and the lesion has a very sharp margin between diseased and healthy tissues (Figure 1a). Spores may appear on the decayed area, starting at the infection site. Decayed fruit has an earthy, musty odor. The causal agent was isolated from the diseased fruits and cultured on PDA medium at $24 \pm 2{ }^{\circ} \mathrm{C}$. After 2-3 days the fungus produced yellowish green colonies (Figure 1b). Microscopic observation revealed that mycelium is septate, with branched conidiophores that are $70 \mu \mathrm{m}-110 \mu \mathrm{m}$ long, biverticillate (one stage branched). Metulae is $7 \mu \mathrm{m}-10 \mu \mathrm{m}$ long. Metulae forms conidiogenous cells called sterigmata or phialides. Sterigmata is $8.50 \mu \mathrm{m}-10.95 \mu \mathrm{m}$ long, and gives rise to conidia that are oval or globose and $1.50 \mu \mathrm{m}-2.20 \mu \mathrm{m}$ in diameter (Figure 1c).
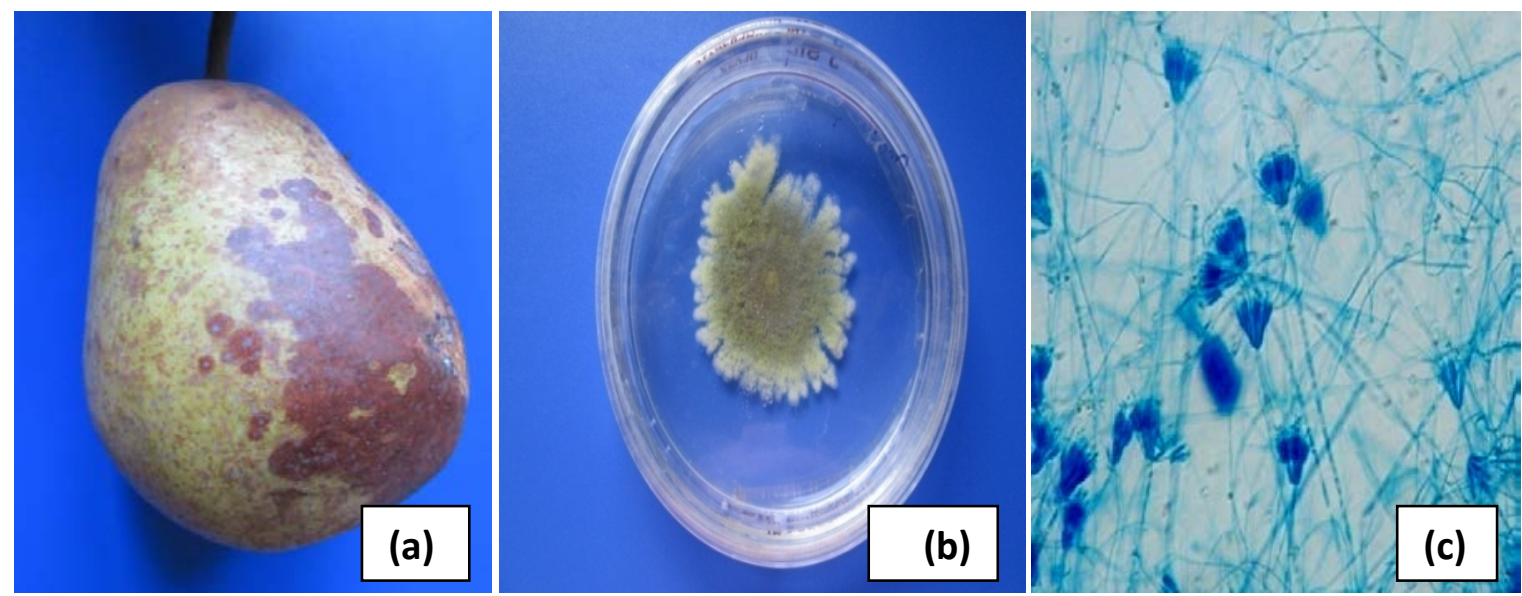

Figure 1. (a). Infected pear, (b). Culture of Penicillium glaucum on PDA, (c). Mycelium of Penicillium glaucum with conidiophores and conidia (400x). 


\section{Control of Penicillium glaucum Link causing Penicillium rot of pear with fungicides}

In the present study, the effect of some fungicides and plant extracts were evaluated on Penicillium glaucum causing Penicillium rot of pear. Different concentrations of fungicides and plant extracts were evaluated for their efficacy on the mycelial growth and spore germination of the test fungi.

\section{Effect of different concentrations of fungicides on the mycelial growth of Penicillium glaucum}

It was revealed from the results (Table 1, Figure 2) that all the fungicides such as carbendazim, hexaconozole, bitertanol and myclobutanil at different concentrations, viz. 1000 ppm, 800 ppm,
600 ppm, 400 ppm and 200 ppm brought about significant reduction in mycelial growth of Penicillium glaucum compared to control. However, carbendazim and hexaconozole was found more effective in inhibiting the mycelial growth followed by bitertanol and myclobutanil at the same concentration. Other concentrations also caused significant reduction in mycelial growth. In different concentrations of carbendazim the inhibition in mycelial growth varies from $100 \%-89.21 \%$ and in hexaconozole the mycelial growth inhibition varies from 100\%-87.07\%, respectively. Likewise, the inhibition in mycelial growth varies from 100\%-80.07\% in different concentrations of bitertanol and in different concentrations of myclobutanil the inhibition in mycelial growth varies from $93.37 \%-72.52 \%$, respectively.

Table 1. Effect of different concentrations of fungicides on the mycelial growth of Penicillium glaucum.

\begin{tabular}{|c|c|c|c|c|c|c|}
\hline \multirow{2}{*}{ Treatment } & \multicolumn{6}{|c|}{ Mycelial growth (mm) } \\
\hline & 200 ppm & 400 ppm & 600 ppm & 800 ppm & 1000 ppm & Control \\
\hline Carbendazim & $\begin{array}{c}4.67 \pm 0.61^{b} * \\
(89.21)\end{array}$ & $\begin{array}{c}2.53 \pm 0.50^{\mathrm{c}} \\
(94.16)\end{array}$ & $\begin{array}{c}0.00 \pm 0.00^{d} \\
(100)\end{array}$ & $\begin{array}{c}0.00 \pm 0.00^{d} \\
(100)\end{array}$ & $\begin{array}{c}0.00 \pm 0.00^{d} \\
(100)\end{array}$ & $43.30 \pm 1.13^{\mathrm{a}}$ \\
\hline Hexaconozole & $\begin{array}{c}5.60 \pm 0.53^{\mathbf{e}} \\
(87.07)\end{array}$ & $\begin{array}{c}3.00 \pm 0.92^{\mathrm{c}} \\
(93.07)\end{array}$ & $\begin{array}{c}0.00 \pm 0.00^{d} \\
(100)\end{array}$ & $\begin{array}{c}0.00 \pm 0.00^{d} \\
(100)\end{array}$ & $\begin{array}{c}0.00 \pm 0.00^{\mathrm{d}} \\
(100)\end{array}$ & $43.30 \pm 1.13^{\mathrm{a}}$ \\
\hline Bitertanol & $\begin{array}{c}8.63 \pm 0.60^{f} \\
(80.07)\end{array}$ & $\begin{array}{c}5.80 \pm 0.92 \mathrm{e} \\
(86.60)\end{array}$ & $\begin{array}{c}3.53 \pm 0.50^{\mathrm{C}} \\
(91.85)\end{array}$ & $\begin{array}{c}1.33 \pm 0.58^{\mathrm{g}} \\
(96.93)\end{array}$ & $\begin{array}{c}0.00 \pm 0.00^{d} \\
(100)\end{array}$ & $43.30 \pm 1.13^{\mathrm{a}}$ \\
\hline Myclobutanil & $\begin{array}{c}11.90 \pm 0.26^{\mathbf{h}} \\
(72.52)\end{array}$ & $\begin{array}{c}9.37 \pm 0.47^{f} \\
(78.36)\end{array}$ & $\begin{array}{c}7.43 \pm 0.58^{\mathrm{i}} \\
(82.84)\end{array}$ & $\begin{array}{c}4.70 \pm 0.43^{\text {be }} \\
(89.14)\end{array}$ & $\begin{array}{c}2.87 \pm 2.81^{\mathrm{c}} \\
(93.37)\end{array}$ & $43.30 \pm 1.13^{\mathrm{a}}$ \\
\hline
\end{tabular}

$*$ Mean \pm S.D of three replicates. Mean values were compared using LSD test $(\mathrm{P}<0.05)$ (Steel and Torrie, 1985). The numbers followed by same alphabets are not statistically different according to LSD test.

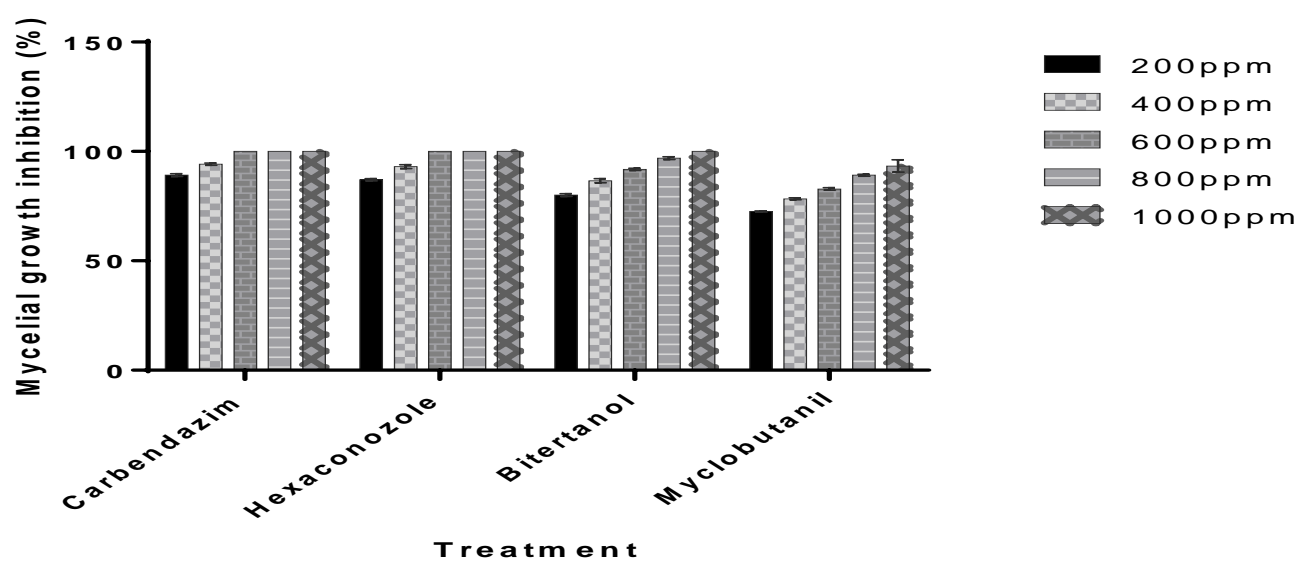

Figure 2. Effect of different concentrations of fungicides on the mycelial growth of Penicillium glaucum. 


\section{Effect of different concentrations of fungicides on the spore germination of Penicillium glaucum}

It was revealed from the results (Table 2, Figure 3) that all the fungicides, viz. carbendazim, hexaconozole, bitertanol and myclobutanil at different concentrations 1,000 ppm, $800 \mathrm{ppm}, 600$ ppm, 400 ppm and 200 ppm caused significant reduction in spore germination of Penicillium glaucum. Amongst the fungicides hexaconozole and carbendazim at highest concentration (1,000 ppm) was found most effective in reducing the germination of spores followed by bitertanol and myclobutanil at the same concentration. The other concentrations also brought about significant reduction in spore germination but to lesser extent. The percentage inhibition in spore germination in carbendazim varies from $25.87 \%-0.00 \%$ in different concentrations. In hexaconozole the inhibition in spore germination varies from $26.58 \%-0.00 \%$ in different concentrations where as in bitertanol the germination of spores varies from $46.26 \%-15.14 \%$ and in myclobutanil the reduction in spore germination varies from $49.19 \%-18.18 \%$ in different concentrations.

Table 2. Effect of different concentrations of fungicides on the spore germination of Penicillium glaucum.

\begin{tabular}{|l|l|l|l|l|l|l|}
\hline \multirow{2}{*}{ Treatment } & \multicolumn{7}{|c|}{ Spore germination (\%) } \\
\cline { 2 - 7 } & $\mathbf{2 0 0} \mathbf{~ p p m}$ & $\mathbf{4 0 0} \mathbf{~ p p m}$ & $\mathbf{6 0 0} \mathbf{~ p p m}$ & $\mathbf{8 0 0} \mathbf{~ p p m}$ & $\mathbf{1 0 0 0} \mathbf{~ p p m}$ & Control \\
\hline Carbendazim & $25.87 \pm 1.15^{\mathbf{b}} *$ & $14.51 \pm 1.00^{\mathbf{c}}$ & $3.24 \pm 1.15^{\mathbf{d}}$ & $0.00 \pm 0.00^{\mathbf{d}}$ & $0.00 \pm 0.00^{\mathbf{d}}$ & $81.25 \pm 0.58^{\mathbf{a}}$ \\
\hline Hexaconozole & $13.58 \pm 1.15^{\mathbf{b}}$ & $2.33 \pm 0.58^{\mathbf{d}}$ & $0.00 \pm 0.00^{\mathbf{d}}$ & $0.00 \pm 0.00^{\mathbf{d}}$ & $0.00 \pm 0.00^{\mathbf{d}}$ & $81.25 \pm 0.58^{\mathbf{a}}$ \\
\hline Bitertanol & $46.26 \pm 1.53^{\mathbf{e}}$ & $38.83 \pm 0.58^{\mathbf{f}}$ & $26.98 \pm 0.58^{\mathbf{b}}$ & $21.89 \pm 0.58^{\mathbf{b}}$ & $15.14 \pm 0.58^{\mathbf{c}}$ & $81.25 \pm 0.58^{\mathbf{a}}$ \\
\hline Myclobutanil & $49.19 \pm 0.58^{\mathbf{e}}$ & $42.41 \pm 0.58^{\mathbf{e f}}$ & $29.68 \pm 1.53^{\mathbf{b}}$ & $23.87 \pm 0.58^{\mathbf{b}}$ & $18.18 \pm 1.00^{\mathbf{c}}$ & $81.25 \pm 0.58^{\mathbf{a}}$ \\
\hline
\end{tabular}

*Mean \pm S.D of three replicates. Mean values were compared using LSD test $(\mathrm{P}<0.05)$ (steel and Torrie, 1985). The numbers followed by same alphabets are not statistically different according to LSD test.
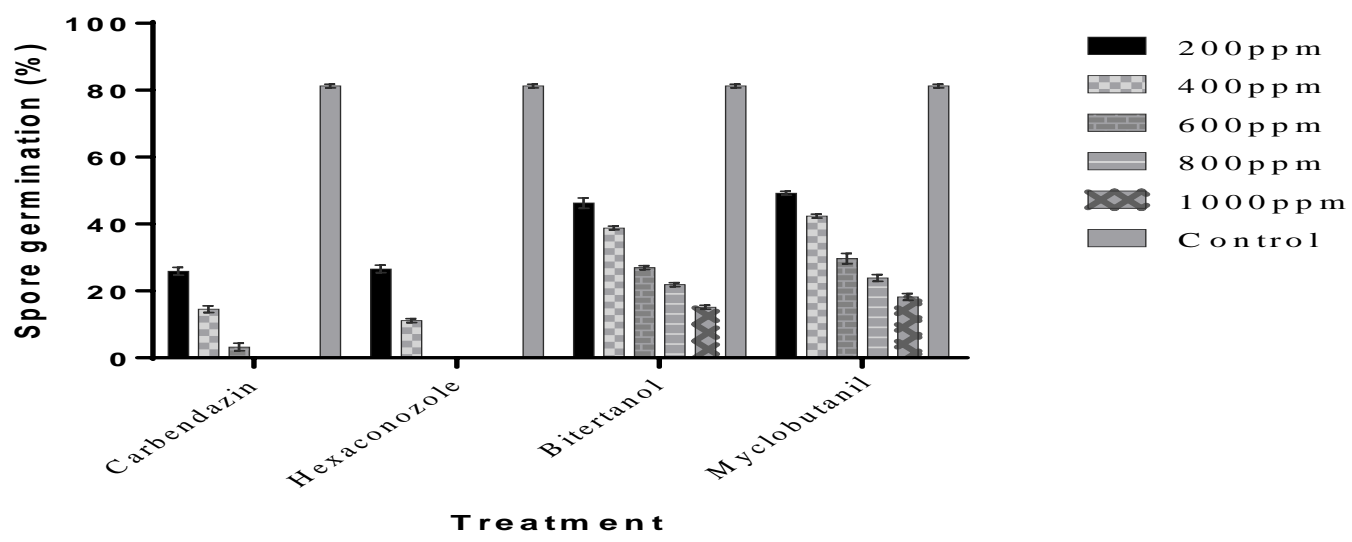

Figure 3. Effect of different concentrations of fungicides on the spore germination of Penicillium glaucum.

\section{Discussion}

It was clear from the results that pear fruits are attacked by Penicillium glaucum Link which is responsible for
Penicillium rot of pear fruits. The occurrence of fungal rot of pears and other fruits due to various other fungi have been reported all over the world by several workers (Sive and Resinizky, 1987; Adikaram, 1988; Singh and Prashar, 1989; 
Snowdon, 1990; Bottcher and Pohle, 1991; Niklis, 1994; Lennox et al., 2004; Xiao and Boal, 2004; Spotts and Castagnoli, 2010; Bashir et al., 2012; Parveen and Wani, 2015; Parveen et al., 2016). Penicillium glaucum have been reported to cause rot of apples and pears in Greece (Giapanoglou et al., 1999). Although many species of Penicillium have been documented to cause fungal rot pears in India, this is the first report of occurrence of Penicillium glaucum on pear fruits in India as per literature survey.

In the present study some fungicides were evaluated for their antifungal activity against the identified fungus, Penicillium glaucum Link. From the results it is clear that all the tested fungicides proved highly effective in reducing the mycelial growth and spore germination of Penicillium glaucum. Amongst the tested fungicides, carbendazim proved highly effective in inhibiting the mycelial growth and spore germination of Penicillium glaucum followed by hexaconozole, bitertanol and myclobutanil respectively. In the previous work, similar findings were reported by Cole et al. (2005), Amini and Sidovich (2010), Rathod et al. (2010), Wani and Taskeen-Un-Nisa (2010), Choudhary et al. (2013), Parveen et al. (2013) on other rot causing fungal pathogens. Vorstermans et al. (2005) used a fungicide Philabuster against the key pathogens viz. Penicillium expansum (blue mold), Botrytis cinerea (grey mold) and Gloeosporium sp. (lenticels rot) causing post harvest rot of apples and pears. Schmidt-Heydt et al., 2013 used seven different fungicides viz. Mancozeb, Rovral, Luna Experience, Aliette, Ortiva, Fenomenal and Ortiva to study their ability to inhibit the growth of fungal pathogens like Penicillium nordicum, Penicillium verrucosum, Verticillium dahlia and Cladosporium sps. and reported that all the fungicides were able to inhibit the growth of analyzed fungi.

\section{Conflict of interests}

The authors declare that there are no conflicts of interest.

\section{References}

Adams, P. B.; Wong, J. A. L. The effect of chemical pesticides on the infection of sclerotia of Sclerotinia minor by the biocontrol agent Sporidesmium sclerotivorum. Phytopathology, v. 81, p. 1340-1343, 1991.

Adikaram, N. K. B. A survey of post harvest losses in some fruits and vegetables and the fungi associated with them. Ceylon Journal of Science, v, 19, p. 1-10, 1988.

Amini, J.; Sidovich, D. F. The effects of fungicides on Fusarium oxysporium f. sp. lycopersici associated with Fusarium wilt of tomato. Journal of Plant Protection Research, v. 50, p. 172-178, 2010.

Barkai-Golan, R. Post-harvest diseases of fruits and vegetables: development and control. Netherlands: Elsevier, 2001.

Barnett, H. L.; Hunter, B. B. Illustrated genera of Imperfect Fungi. 3 ed. Minnesota: Burgess Publishing Company, 1972.

Bashar, M. A.; Shamsi, S.; Hossain, M. Fungi associated with rotten fruits in Dhaka Metropolis. Bangladesh Journal of Botany, $\begin{array}{lll}\text { v. } 41, \quad \text { no. } 2, \quad \text { p. } 115-117, & 2012 .\end{array}$ http://dx.doi.org/10.3329/bjb.v41i1.11090

Bhale, U. N. Survey of market storage diseases of some important fruits of Osmannabad District, India. Science Research Reporter, v. 1, no. 2, p. 88-91, 2011. Available from: <http://jsrr.net/Volume 1 No 2/Bhale 4548.pdf $>$. Accessed on:

Bhat, N. M.; Sivaprakasan, K. Antifungal activity of some plant extracts. In: Sivaprakasan, K.; Seetharaman, I. (Eds.). Crop innovation techniques and management. New Delhi, India: Kalyani Publishers, 1994. . p. 335339.

Blattny, C. Pears. In: Caballero, B.; Trugo, L. C.; Finglas, P.M. (Eds.). Encyclopedia of food sciences and nutrition. London: Academic Press, 2003. p. 4428-4433.

Bottcher, H.; Pohle, K. Studies on the occurrence of post harvest decay of garlic bulbs (Allium sativum L.). Archiv für Phytopathologie und Pflanzenschutz, v. 27, p. 445-457, 1991.

Choudhary, C. S.; Jain, S. C.; Kumar, R.;

Choudhary, J. S. Efficacy of different fungicides, biocides and botanical extract seed treatment for controlling seed borne Colletotrichum sp. in chilli (Capsicum annum L.). The Bioscan, v. 8, p. 123-126, 2013. 
Colaric, M.; Veberic, R.; Stampar, F.; Hudina, M. Evaluation of peach and nectarine fruit quality and correlations between sensory and chemical attributes. Journal of Science of Food and Agriculture, v. 85, no. 15, p. 2611-2616, 2005. https://dx.doi.org/10.1002/jsfa.2316

Cole, J. T.; Cole, J. C.; Convey, E. C. Effectiveness of selected fungicides applied with or without surfactant in controlling anthracnose on three cultivars of Euonymous fortunei. Journal of Applied Horticulture, v. 7, no. 1, p. 16-19, 2005.

Ellis, M.B. Dematiaceous Hypomycetes. England: Common Wealth Mycological Institute, 1971.

Giapanoglou, E.; Karagounakis, S.; Spyrianidou, H.; Thanassoulopoulos, C. C. Postharvest losses of perishable commodities caused by fungi in Macedonia. In: Gerasopoulos, D. (Ed.). Post-harvest losses of perishable horticultural products in the Mediterranean Region. Chania: CIHEAM, 1999. p. 63-68.

Gilman, J.C. A manual of soil fungi. Iowa: Iowa State University Press, 2008.

Hudina, M.; Stampar, F. Sugars and organic acids content of European pear (Pyrus communis L.) and Asian pear (Pyrus serotina Rehd.) cultivars. Acta Alimentaria, v. 29, p. 217-230, 2000. https://doi.org/10.1556/AAlim.29.2000.3.2

Kiraly Z.; Klement Z.; Solymosy F.; Voros J. Methods in plant pathology with special reference to breeding for ressistance to breeding for resistance. New York: Elsevier, 1974.

Lennox, C. L.; Spotts, R. A.; Booyse, M. Incidence of postharvest decay of 'd'Anjou' pear and control with a thiabendazole drench. Plant Disease, v. 88, p. 474-478, 2004. https://dx.doi.org/10.1094/PDIS.2004.88.5.474

Macheix, J. J.; Fleuriet, A.; Billot, J. Fruit Phenolics. Boca Raton, FL: CRC Press, 1990.

Nikilis, N. D. The role of Botrytis cinerea Pers. fungus in the production and the biosynthesis of ethylene during the storage of kiwifruit cv "Hayward" at reduced temperature and low oxygen concentrations. Thessaloniki, Greece: Faculty of Agriculture of the Aristotelian, University of Thessaloniki, 1994. (Ph.D. Thesis).

Parveen, S.; Ganie, A. A.; Wani, A. H. In vitro efficacy of some fungicides on mycelial growth of Alternaria alternata and Mucor piriformis. Archives of Phytopathology and Plant
Protection, v. 46, p. 1230-1235, 2013. https://dx.doi.org/10.1080/03235408.2013.7636 17

Parveen, S.; Wani, A. H. In Vitro efficacy of some fungicides and plant extracts on Mucor piriformis Fisher causing postharvest rot of peach in Kashmir Valley. Trends in Biosciences, v, 8, p. 620-627, 2015.

Parveen, S.; Wani, A. H.; Bhat, M. Y.; Koka, J. A.; Wani, F. A. Management of postharvest fungal rot of peach (Prunus persica (L.) Batsch) caused by Rhizopus stolonifer (Ehrenb.:Fr.) Vuill. in Kashmir Valley, India. Plant Pathology and Quarantine, v. 6, p. 19-29, 2016.

Schmidt-Heydt, M.; Stoll, D.; Geisen, R. Fungicides effectively used for growth inhibition of several fungi could induce mycotoxin biosynthesis in toxigenic species. International Journal of Food Microbiology, v. 166, p. 407-412, 2013. https://doi.org/ 10.1016/j.ijfoodmicro.2013.07.019

Singh, R. S.; Prashar, M. Post-harvest spoilage of peach and plum fruits in north India due to Aspergillus. Journal of Research, v. 26, p. 62-64, 1989.

Sive, A.; Resinizky, D. Fogging: a new method of post-harvest treatment of apples. Conclusions from experiments in the $1987 / 88$ season. Alon Hanotia, v. 43, p. 23-27, 1987.

Snowdon, A. L. A colour atlas of post-harvest diseases and disorders of fruits and vegetables. Wolf Scientific, 1990. v. 2.

Spotts, R. A.; Castagnoli, S. Predicting and managing gray mold rot of pear in Oregon. Corvallis, Oregon: Oregon State University, 2010.

Tomkin and Trout, Pricking by Entomological pins (C-Dass Gupta and Mandal: 1989). 1931.

Vorstermans, B.; Creemers, P.; Bylemans, D.; Garnier, A. A new post-harvest fungicide to control fruit rot on apple and pear. Communications in Agriculture and Applied Biological Science, v. 70, no. 3, p. 79-89, 2005.

Wani, A. H.; Taskeen-Un-Nisa. Management of black mold rot of onion. Mycopath, v. 9, no. 1, p. 43-49, 2011. Available from: $<$ http://pu.edu.pk/images/journal/impp/PDF-

FILES/10-Final-Wani-_vol 9(1)2011.pdf >. Accessed on:

Watanabe, T. Pictorial atlas of soil and seed fungi: morphologies of cultured fungi and key to species. 2 ed. Boca Raton, Florid: CRC Press, 2002. 
Xiao, C. L.; Boal, R. J. Prevalence and incidence of Phacidiopycnis rot in d'Anjou pears in Washington State. Plant Disease, v. 88, p. 413-418, 2004. http://dx.doi.org/10.1094/ PDIS.2004.88.4.413

License information: This is an open-access article distributed under the terms of the Creative Commons Attribution License, which permits unrestricted use, distribution, and reproduction in any medium, provided the original work is properly cited.

Braz. J. Biol. Sci., 2017, v. 4, No. 8, p. 265-272. 